\title{
AZ ÁRAMLÁS- ÉS HŐTECHNIKAI GÉPEK TANSZÉK TÖRTÉNETE 1952-2019
}

\author{
Szabó Szilárd \\ egyetemi tanár, Miskolci Egyetem, Energetikai és Vegyipari Gépészeti Intézet, \\ Áramlás- és Hötechnikai Gépek Intézeti Tanszék \\ 3515 Miskolc, Miskolc-Egyetemváros, e-mail: aram2xsz@uni-miskolc.hu
}

\section{Schifter Ferenc}

nyugalmazott föiskolai docens, Miskolci Egyetem, Energetikai és Vegyipari Gépészeti Intézet, Áramlás- és Hötechnikai Gépek Intézeti Tanszék

3515 Miskolc, Miskolc-Egyetemváros, e-mail:aram2xsz@uni-miskolc.hu

\begin{abstract}
Absztrakt
A Gépészmérnöki és Informatikai Kar alapitásának 70. évfordulójához kapcsolódva ismertetjük a Karon belül 1952-ben létrehozott Áramlás- és Hőtechnikai Gépek Tanszékének 67 éves történetét. E tanszék alapitásától fogva egyik meghatározója a Karon folyó oktatási és kutatási tevékenységnek. Olyan témakörök tartoznak müködési területéhez, amelyek a világ összes müszaki egyetemén a gépészmérnök képzés szerves részét képezik. A Tanszék alapitása óta vallja és gyakorolja azt az elvet, hogy korszerü oktatás nincs kutatás nélkül. A tanszék mindenkori oktatógárdája ennek alapján végezte tevékenységét.
\end{abstract}

Kulcsszavak: áramlástan, hőtan, áramlástechnikai gépek, hötechnikai gépek, energetika, környezetvédelem

\begin{abstract}
In this paper written on the occasion of the 70th anniversary of the Faculty of Mechanical Engineering and Informatics, the history of the Department of Fluid and Heat Engineering is presented that was founded in 1952. Since its foundation it plays very important role in both education and research activities. It covers disciplines that are integral parts of mechanical engineering education system at technical universities all over the world. The principle that modern education cannot exist without research is followed by the department since its foundation. The teaching staff (former and current) belonging to the Department of Fluid and Heat Engineering was committed to this principle.
\end{abstract}

Keywords: fluid and heat engineering, fluid and heat machinery, energetics, protection of the environment

\section{Bevezetés}

A tanszék az alapítása óta eltelt évtizedek alatt mind szervezetileg, mind a kijelölt célokat tekintve jelentős változásokon ment keresztül. E változások érintették az infrastruktúrát, a személyi állományt, valamint az oktatási és kutatási tevékenységet. A következőkben ezeket foglaljuk össze [1-4]. 


\section{A tanszék története}

A Tanszéket az Oktatásügyi Minisztérium az 1951. évi 26. számú törvényerejü rendelettel hozta létre a Nehézipari Müszaki Egyetem Gépészmérnöki Karán Gépüzemtani Tanszék megnevezéssel. A Tanszék neve oktatási és kutatási profiljának kialakulása után 1965. március 15-étől az 52341/1965. MM. sz. rendelet alapján Áramlás és Hőtechnikai Gépek Tanszékére változott. 2015-ben a Karon bevezetésre került az intézeti rendszer. Ennek keretében a Tanszék a Vegyipari Gépek Tanszékkel közösen egy intézetben, az Energetikai és Vegyipari Gépészeti Intézetben folytatja tevékenységét intézeti tanszékként (Áramlás- és Hötechnikai Gépek Intézeti Tanszék).

A Tanszék első vezetője Lancsarics Alajos (1903-1963) volt. Lancsarics Alajos professzor 1962ben súlyosan megbetegedett és ezért ideiglenes jelleggel Dr. Vida György vette át a Tanszék irányítását. Lancsarics professzor halála után 1963-ban azt a Dr. Czibere Tibort hívták meg a Tanszék élére, aki korábban az Egyetem oktatója volt, abban az időben pedig a Ganz-Mávag Központi Vízgéptervező Irodájában kutatómérnöki beosztásban dolgozott. Dr. Czibere Tibor ezt követően negyedszázadon át vezette a Tanszéket.

Amikor Czibere professzor 1988-ban oktatási miniszter lett, Dr. Nyíri András lépett a helyére. Ö szintén a Ganz-Mávagból érkezett, ahol a Vízgép és Kompresszor Tervezési Főosztály vezetője volt. A Tanszék sem volt ismeretlen számára, mert már évek óta félállású docensként részt vett annak munkájában. 1996-ban betöltötte 65. életévét és emiatt megbízatása lejárt. Utóda Dr. Szabó Szilárd professzor lett, aki 1975 óta a Tanszék oktatója volt, s aki 20 év tanszékvezetői tevékenység után 2016ban átadta a Tanszék vezetését tanítványának, Dr. Bencs Péternek, a jelenlegi tanszékvezetőnek. A tanszékvezetők fényképeit a mutatja az 1. ábra.

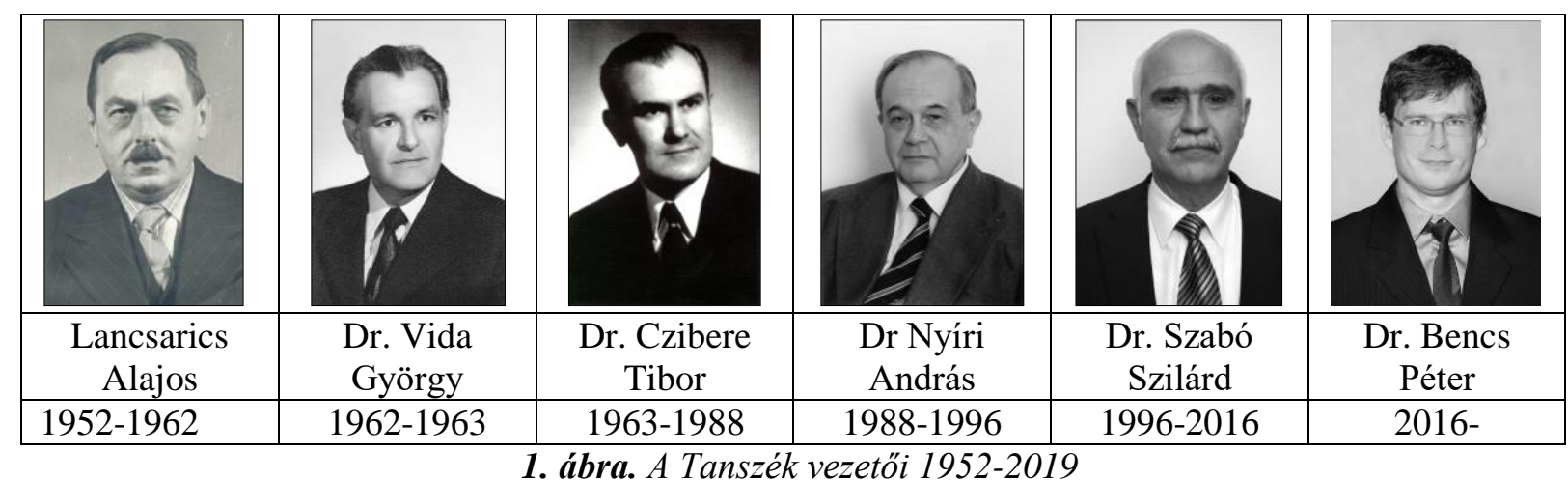

A 2. ábra a Tanszék elnevezéseinek és tanszékvezetőinek időrendjét mutatja.

A Tanszék alapításakor Lancsarics professzoron kívül 4 tanársegéd, 1 szakmunkás és 1 gépírónő alkotta a személyzetet (3. ábra). A Tanszék oktató gárdája az első években gyakran változott (4. ábra), de az 1970-es évek végére kialakult egy olyan csapat, amely azután hosszabb ideig meghatározója volt a Tanszék tevékenységének. 


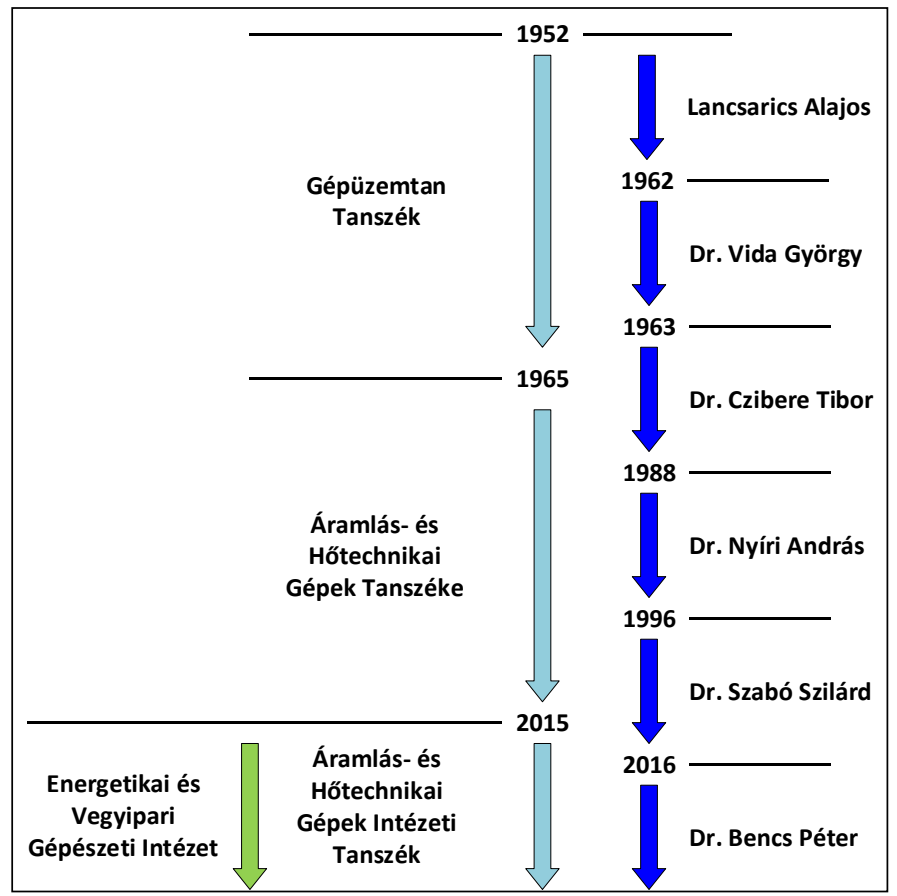

2. ábra. A Tanszék szervezeti felépitésének és vezetöinek változása

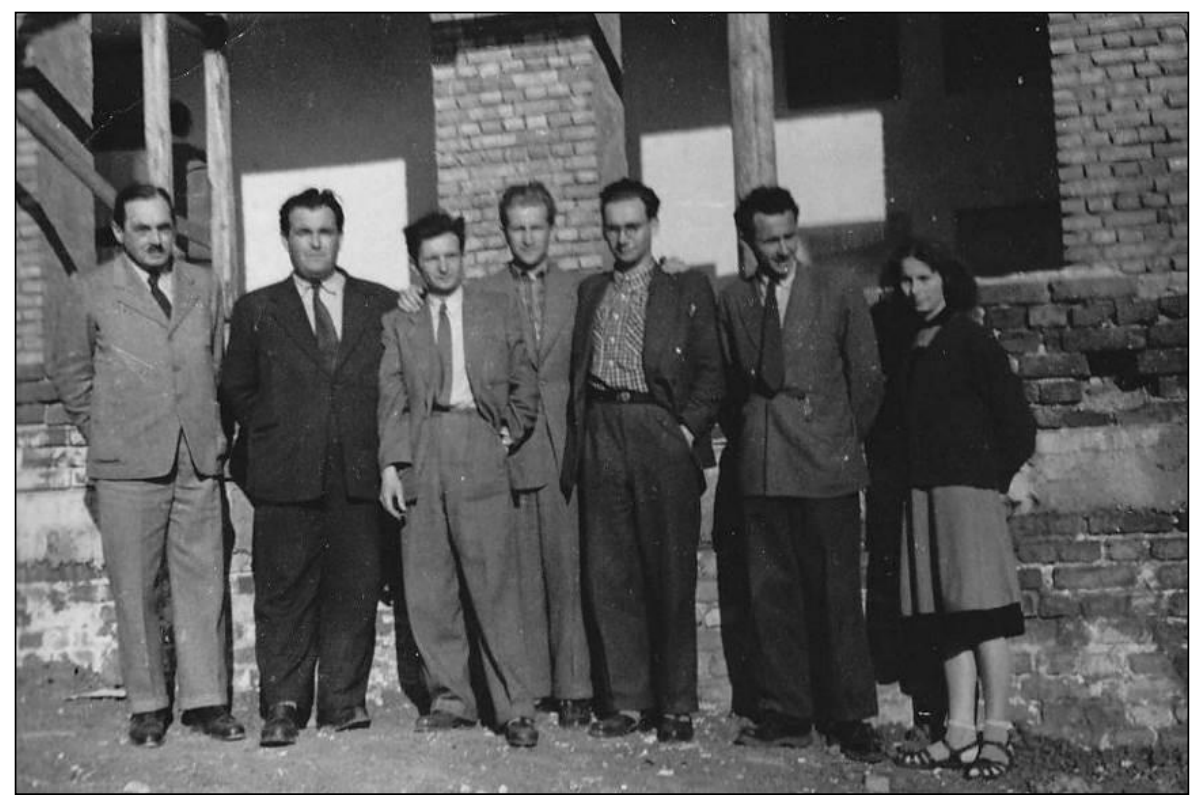

3. ábra. A Tanszék alapitó személyzete egy fövel bövülve 1953-ban az épülö E/5 kollégium elött. Balról: Lancsarics Alajos tanszékvezetö, Vida György tanársegéd, Pintér Kálmán tanársegéd, Résch Pál tanársegéd, Leicht Ernö tanársegéd, Cserny József tanársegéd, Nemes Julia gépirónö 


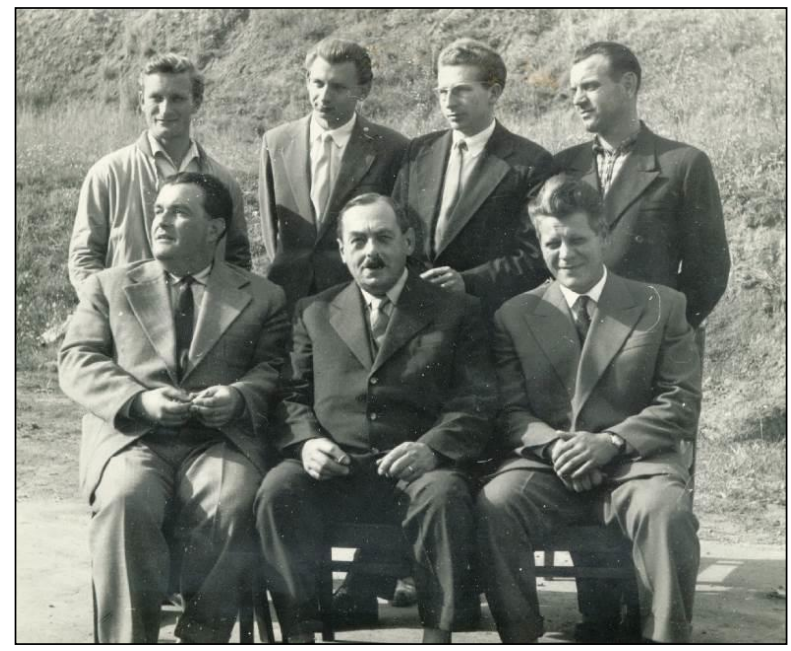

4. ábra. A Tanszék dolgozóinak csoportja 1957-ben.

Elöl balról: Vida György adjunktus, Lancsarics Alajos professzor, Gedeon Árpád tanársegéd; álló balról: Ábrahám Kálmán technikus, Nánási Tibor tanársegéd,

Hajós Mihály tanársegéd, Babics László szakmunkás

A Tanszéknek 1952 és 2019 között 109 munkatársa volt. A munkatársak beosztás szerinti csoportosítását foglalja össze az 1. táblázat és az 5. ábra. Az összes munkatárs felsorolását tartalmazza a 6. ábra. Látható, hogy a Tanszék létszáma 1977 és 2012 között volt a legmagasabb. Ennek oka, hogy Dr. Czibere Tibor tanszékvezetőként - tudatosan - az alkalmazott mechanikai ágazaton végzett hallgatók közül 1972 és 1976 között többeket felvett a Tanszék munkatársai közé. Az így kialakult törzsgárda (lásd 7. ábra) egészen a 2010-es évek elejéig nyújtott kiváló teljesítményt a bonyolultabb körülmények között is. Ekkor azonban a nyugdíjkorhatárt elérve, tanévenként többen kényszerüen kiléptek a Tanszék kötelékéből. Azóta létszámában csökkent, de fiatalabb életkorú személyzet látja el az oktatási- kutatási feladatokat. A 8. ábra a jelenlegi tanszéki csoportképet mutatja.

1. táblázat. A Tanszék munkatársainak beosztás szerinti összetétele 1952-2019

\begin{tabular}{|c|c|c|c|c|c|c|c|c|}
$\begin{array}{c}\text { tanszék } \\
\text { életkora }\end{array}$ & dátum & $\begin{array}{c}\text { oktató- } \\
\text { kutató }\end{array}$ & $\begin{array}{c}\text { prof. } \\
\text { emeritusz }\end{array}$ & $\begin{array}{c}\text { tanszéki } \\
\text { mérnök }\end{array}$ & doktorandusz & $\begin{array}{c}\text { segéd- } \\
\text { személyzet }\end{array}$ & $\begin{array}{c}\text { összes } \\
\text { okt. kut. }\end{array}$ & létszám \\
\hline 0 & 1952 & 5 & 0 & 0 & 0 & 2 & 5 & 7 \\
\hline 1 & 1953 & 7 & 0 & 0 & 0 & 6 & 7 & 13 \\
\hline 10 & 1962 & 7 & 0 & 0 & 0 & 6 & 7 & 13 \\
\hline 20 & 1972 & 11 & 0 & 0 & 0 & 4 & 11 & 15 \\
\hline 25 & 1977 & 14 & 0 & 0 & 0 & 10 & 14 & 24 \\
\hline 45 & 1997 & 11 & 0 & 1 & 2 & 4 & 14 & 18 \\
\hline 50 & 2002 & 10 & 2 & 1 & 7 & 4 & 20 & 24 \\
\hline 55 & 2007 & 9 & 2 & 1 & 2 & 4 & 14 & 18 \\
\hline 60 & 2012 & 14 & 2 & 1 & 0 & 4 & 17 & 21 \\
\hline 65 & 2017 & 7 & 1 & 1 & 1 & 3 & 10 & 13 \\
\hline 67 & 2019 & 7 & 1 & 3 & 2 & 2 & 13 & 15 \\
\hline
\end{tabular}




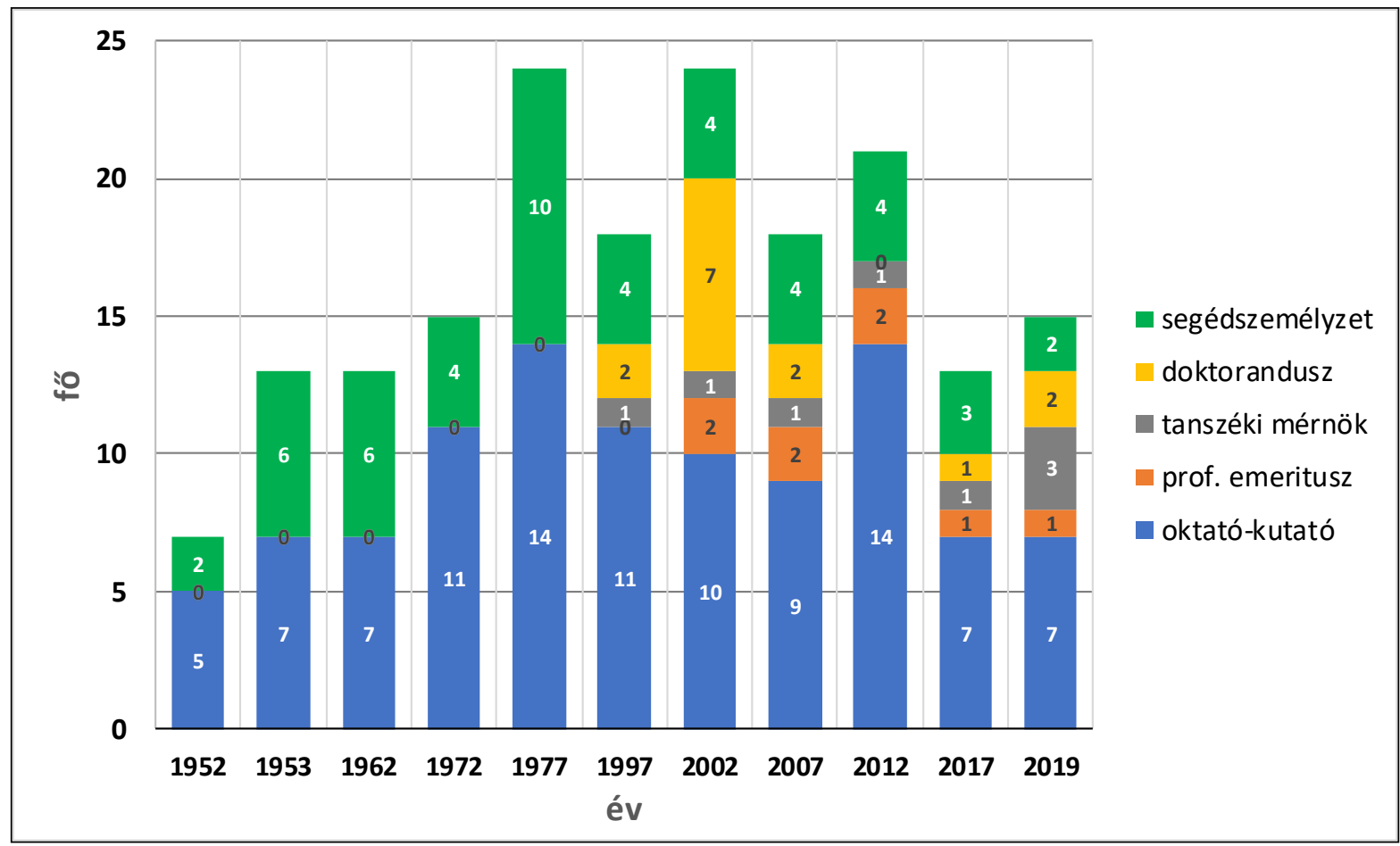

5. ábra. A Tanszék munkatársainak beosztás szerinti összetétele 1952-2019

Ábrahám Kálmán Ambrus Barna Babits László Baranyi László Barta János Baumel Károly Báthori Györgyné Bencs Péter Benke Mátyás Bianky József Bianky Józsefné Bobok Elemér Bolló Betti Boros Gábor Boros István Czibere Tibor Cserny József Csorba Barnabás Dankó Istvánné Deák Sarolta Denk László Dombi Károly Dorogi Dániel Erdélyiné Nagy Ildikó Faragó Dávid Farkas András Farkas László Farkasovszky István Fáy Árpád Fáy Csaba Fekete Lászlóné Fetterné Taksás Mónika Fodor Béla Gál Orsolya Gedeon Árpád Gédl Ferenc Glambusz János Grób János Gyulai György Hajós Gyula Hajós Mihály Handki Andrea Hauser János Herbst Károly Hortobágyi Károly Jakab Zsolt Janiga Gábor Jánosik Ferencné Juhász András Kalmár László Karaffa Ferenc Kassai Gyula Kelemen József Keszler József Kiss Flóriánné Kolcza József Kollonai Nikoletta Kovács Helga Kovács István Kovácsházy Ernő Kozaróczy Miklós Könözsy László Laboda Gyula Lakatos Károly Lancsarics Alajos Leicht Ernő Liptai Zoltán Lukács Tamás Matherni Levente Mátrai Zsolt Nagy Józsefné Nagy László Nagy László Nagy Tibor Nánási Tibor Nemes Júlia Nyíry András Ortutay Miklós Pancsovay Rezső Pintér Kálmán Posta Barna Ramada Zoltán Résch Pál Strázsa Tiborné Schifter Ferenc, Szabó Ádám Szabó Benő Szabó Szilárd Szaszák Norbert Székely Ferenc Szűcs Zoltán Takács Csabáné Takács Dániel Takács József Tausch Rezsőné Tieber József Tollár Sándor Tolvaj Béla Tóth Lajosné Tóth Róbert Turcsányi Lajosné Újvárosi Sándor Vékony János Vékony Klára Vida György Vincze László Visnyei László Voith Katalin Zádori Lajos

6. ábra: A tanszék dolgozói 1952-2019 


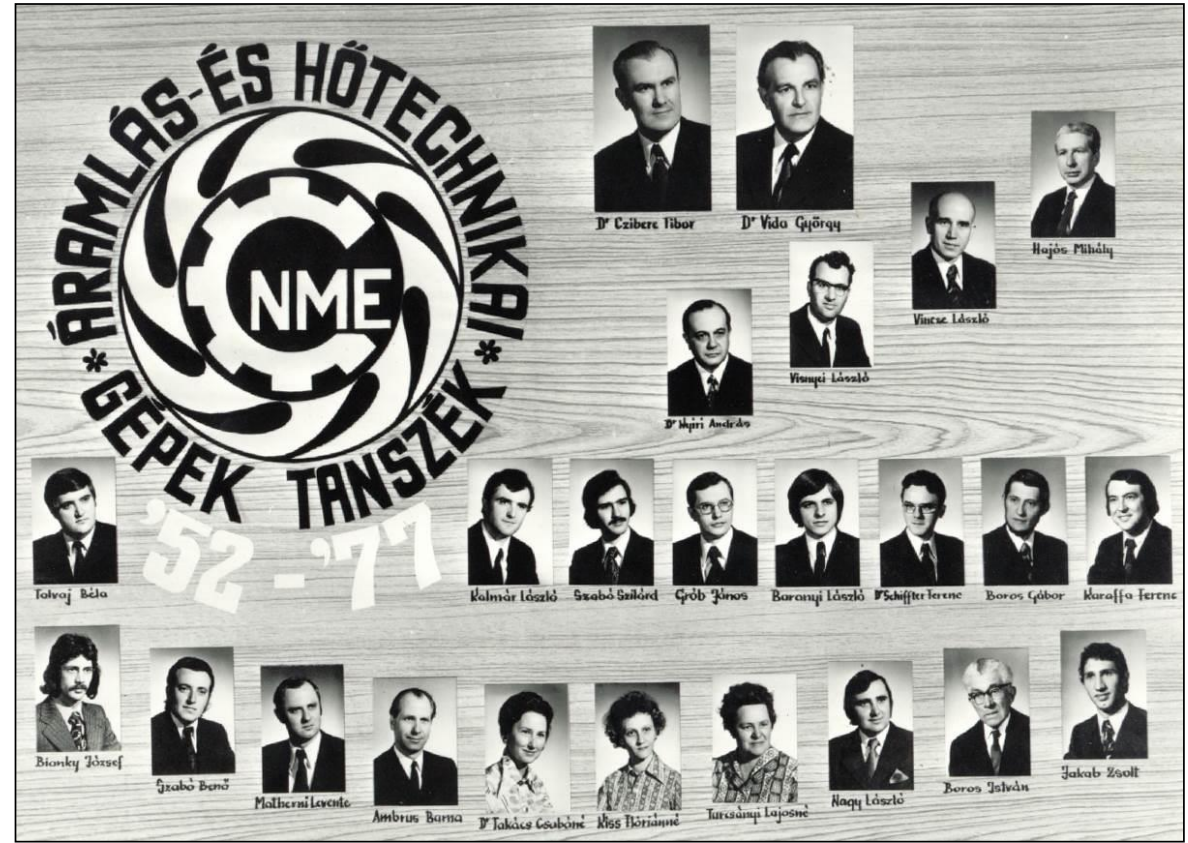

7. ábra: A Tanszék dolgozói a negyedszázados évforduló évében

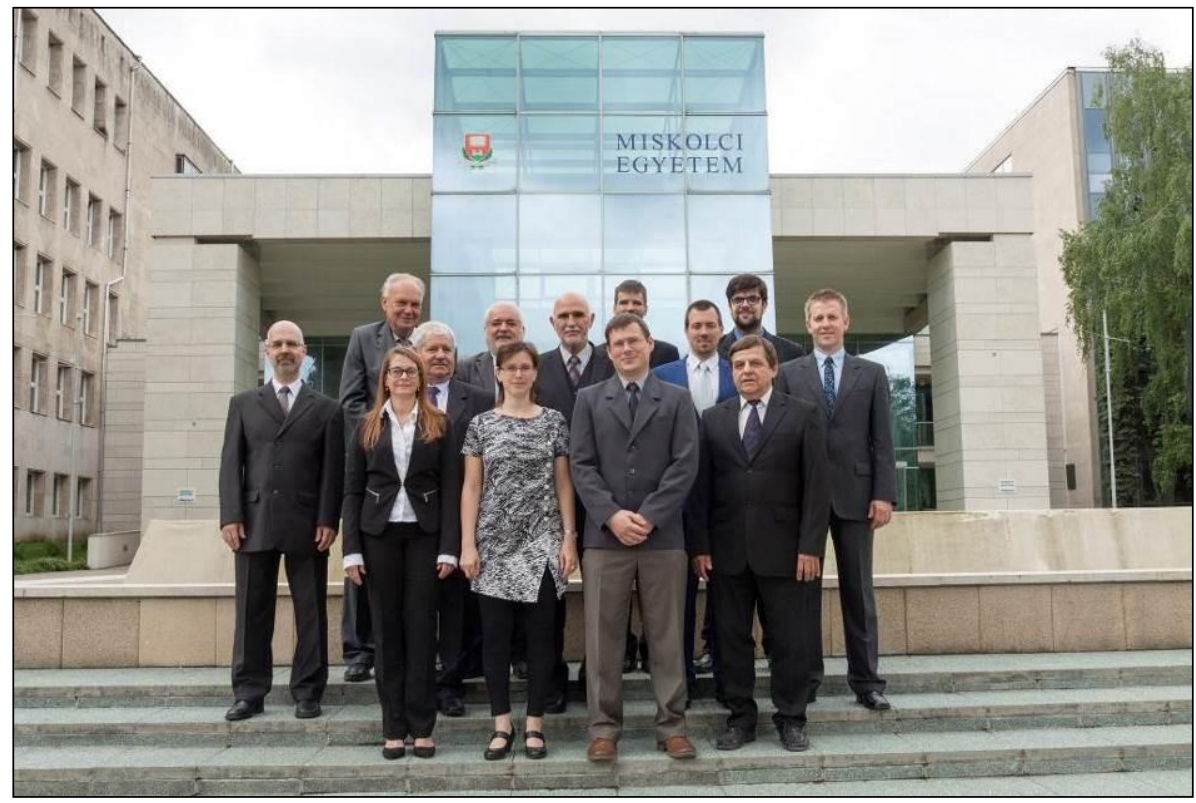

8. ábra. A tanszék dolgozói 2019-ben

Elöl balról: Dr. Voith Katalin tudományos munkatárs, Dr. Bolló Betti egyetemi docens, Dr. Bencs Péter tanszékvezetö egyetemi docens, Dr. Baranyi László professzor,

hátul balról: Bozzay Péter tanszéki mérnök, Farkas László müszaki szolgáltató, Ramada Zoltán müszaki szolgáltató, Farkas Adrás tanszéki mérnök, Dr. Szabó Szilárd professzor, Faragó Dávid doktorandusz,

Dr. Szaszák Norbert egyetemi adjunktus, Dorogi Dániel doktorandusz, Fodor Béla tanszéki mérnök hiányzik a képröl: Prof. Dr. Czibere Tibor professzor emeritusz, Tollár Sándor mesteroktató 
A Tanszék első évei az egész Egyetemre jellemző lázas igyekezettel teltek el, amelyben a lelkesedés úrrá tudott lenni a hiányosságokon és nehézségeken. Ideiglenes volt a Tanszék elhelyezése az E/5 diákszálló I. emeletén, ideiglenes volt a laboratórium az A/1 épület közelében lévő felvonulási épüle-

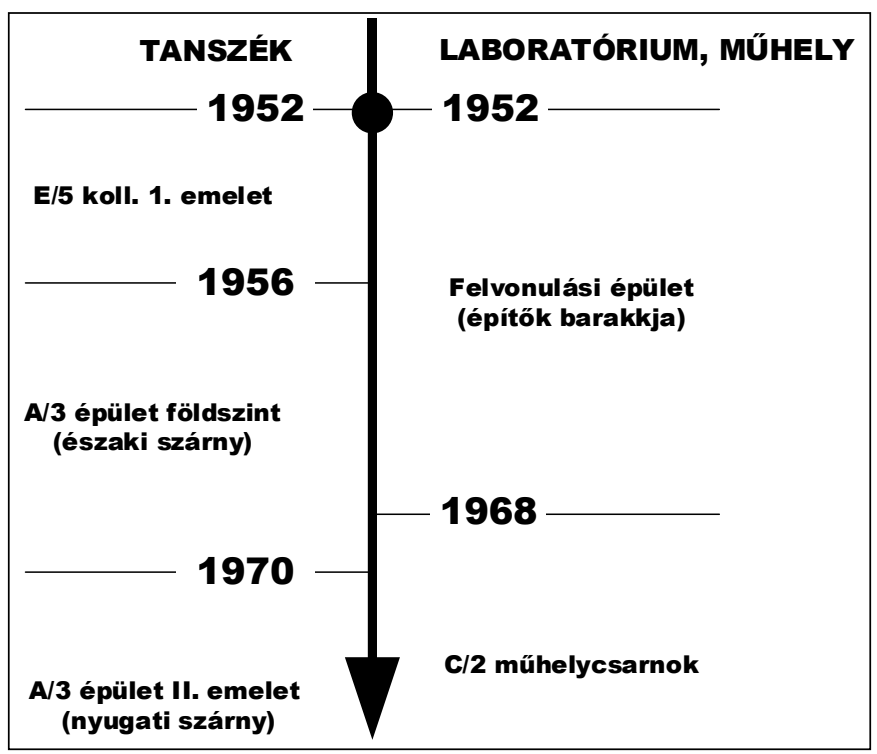

tekben, sokszor változott a személyzet, de mindezek ellenére sikerült megteremteni a későbbi továbblépés alapjait. Közel két évtized elmúltával jelentősen javultak a munkafeltételek is, ezt 1968. október 29-én a laboratórium avatása, majd 1970-ben a Tanszék jelenlegi helyének elfoglalása jelezte (9. ábra).

A tanszéki laboratórium 2007-ben, a Tanszék irodái pedig 2010-ben jelentős felújításon estek át. A változások érzékeltetésére álljon itt két összehasonlító fényképsor. A 10. ábra a tanszéki laboratórium fejlődését érzékelteti.

\section{9. ábra. A tanszék helyváltoztatásainak} története

A Tanszék kezdetben az egyetemet építő rabok barakkjaiból átalakított felvonulási épületek egyikében kapott helyet laboratóriumának kialakítására. Minőségi változást hozott az 1969-ben induló nagy laboratórium, amely több jelentős fejlesztés mellett a mai napig szolgálja az oktatást- kutatást.

A Tanszék egyik volt és ismét előtérbe került szakterülete a belsőégésủ motorok áramlás- és hőtechnikájának elméleti és gyakorlati kérdései. Az eltelt 70 évet érzékeltetik a kezdeti és a jelenlegi motorlaboratóriumról készült fényképek (11. ábra).

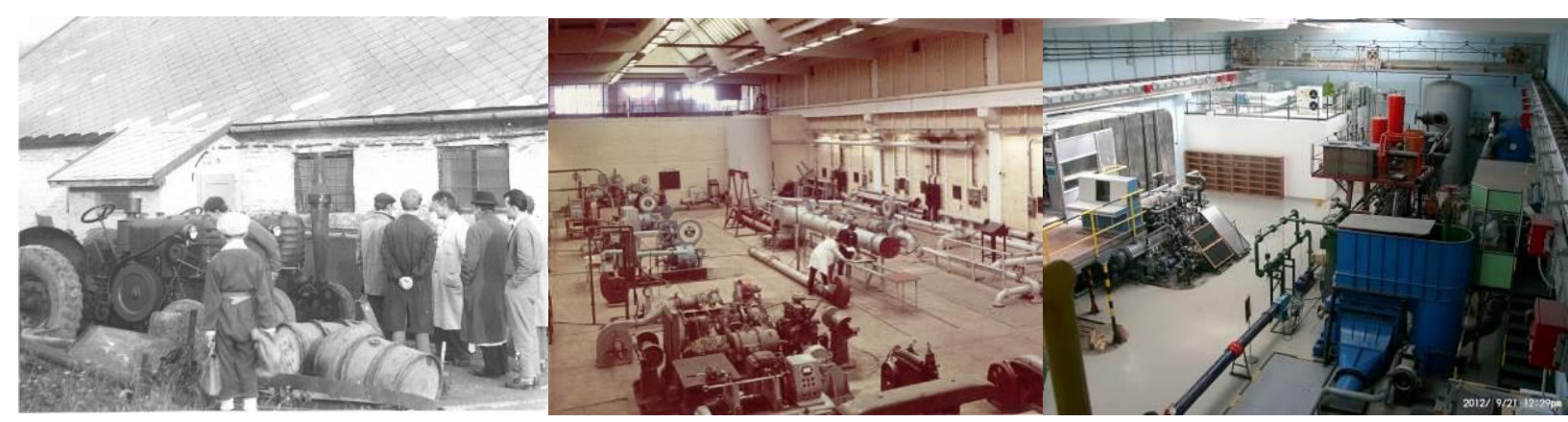

A tanszéki „labor” elött a

Tanszék munkatársai az ötvenes évek elején
A jelenlegi laboratórium az avatás után 1969-ben
A laboratórium a felújítás után 2012-ben

10. ábra. A tanszéki laboratórium fejlödése 

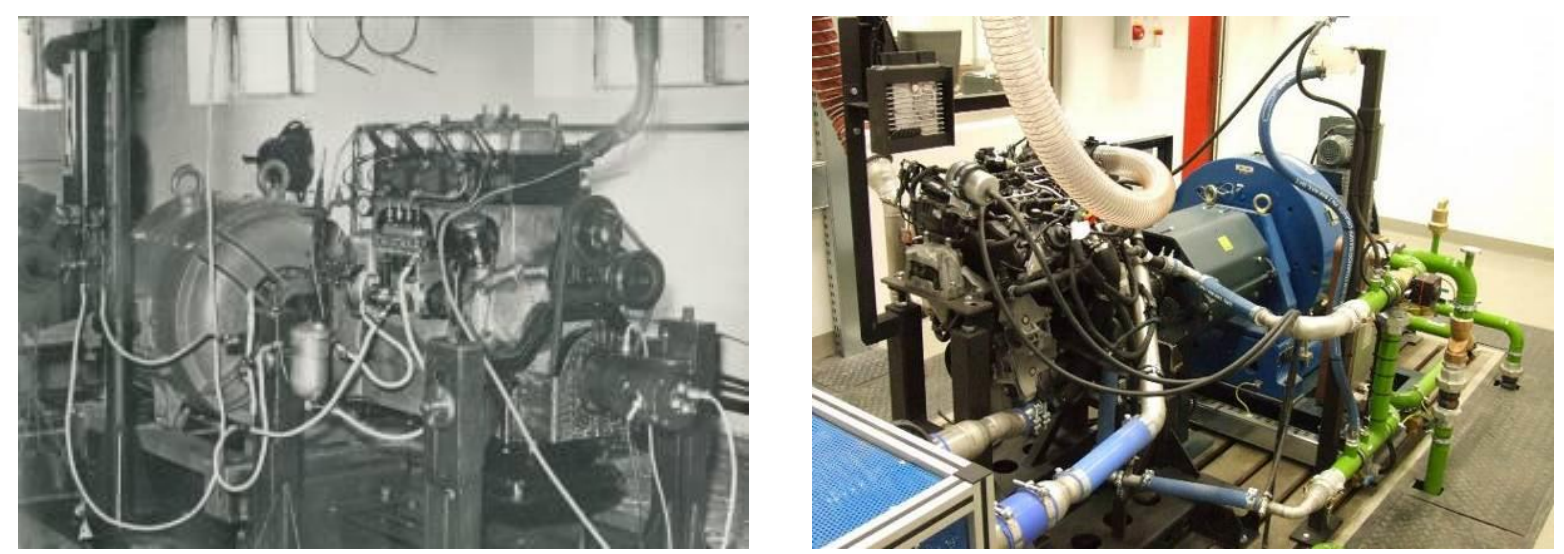

11. ábra. Motorvizsgálat a felvonulási épületbeli géplaborban az 1950-es években, illetve az új diagnosztikai laborban 2012-ben

A Gépüzemtan Tanszék nevéhez híven foglalkozott gépjármüvek üzemeltetésével is. A kezdeti időszakban volt a tanszéknek tehergépkocsija, traktorja, több motorbiciklije és több Skoda személyautója is (12. ábra). A hallgatók tanulhattak motort, kombájnt, sőt gőzmozdonyt vezetni. A Tanszék fiatal tanársegédei gyakran az oldalkocsis motorkerékpáron vitték Lancsarics professzort Budapestre gépbeszerzésre. A jármüvek a személyi változások és az oktatási profil átalakulása során selejtezésre kerültek, pedig egy Hofherr HSCS G35 izzófejes traktor, egy lánctalpas Sztalinyec 80, vagy egy nyitott Skoda Colonial ma már nagy értéket képviselne.

Az új laboratórium üzembe helyezésekor annak egyik fele belső égésủ motorok vizsgálatára szakosodott, míg a másik fél szolgálta a vízgépészetet és a légtechnikát (10. ábra középső képe). Mindkettőt segítette a csarnok alatt létesített medence és kútrendszer.

Az 1970-es évek közepétől a laboratóriumban fokozatosan visszaszorult a motorvizsgálat és előtérbe kerültek az áramlás- és hőtechnikai berendezések. Ezt két nagyértékü és nagyméretű berendezés kialakítása is jelezte. Elkészült egy áramlásmérők kalibrálására szolgáló, vízzel müködő nagypontosságú mérőkör. Ez évtizedekig szolgálta a turbinás áramlásmérők fejlesztését többek között az egykori Vegyépszer megrendelésére. Ez a Vegyépszer gyártotta egyébként miskolci iparmüvészek tervei alapján a miskolci úgynevezett Centrum-szökőkutat, amit áramlástani szempontból a Tanszék alakított ki. Az előzetes kísérletek után a tanszéki dolgozók készre szerelték a teljes rendszert és azt tökéletes müködő állapotban adtuk át a városnak. A másik nagyberendezés egy hütőházi hőcserélők vizsgálatára épített hőszigetelt szélcsatorna volt. Ez az akkori Diósgyőri Gépgyár léghütő fejlesztését segítette. A gyár a légcsatorna létesítéséhez anyagi és gépészeti segítséget nyújtott. A tervezést, összeállítást, müszerezést és üzembe helyezést az a tanszéki csoport vállalta, amelyik fel tudta használni a korábban létesített nyitott szélcsatornával szerzett tapasztalatokat. E szélcsatorna (ami Magyarországon még most is egyedülálló) átépítés és korszerüsítés után mind a mai napig üzemel. A 10. ábra jobb szélső képének bal oldalán a szélcsatorna, jobb oldalán a térfogatáram kalibráló kör átváltója látható. 


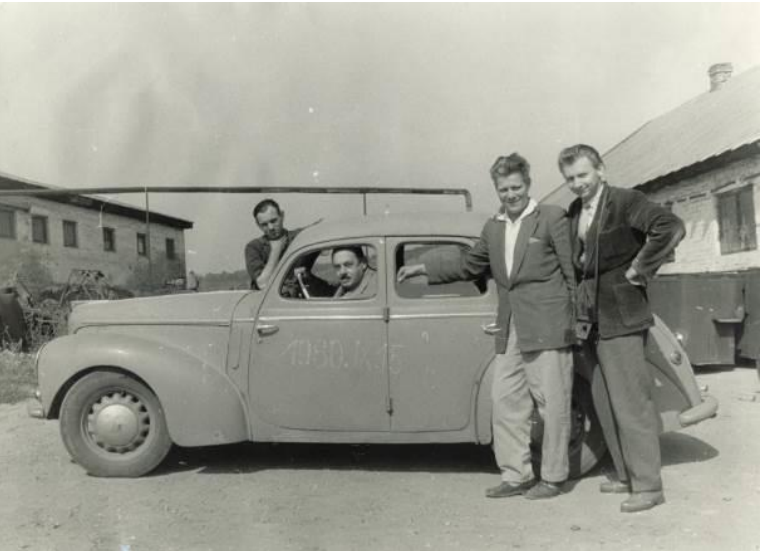

A tanszéki Skoda gépkocsi 1960. 09. 15-én

(Babics László, Lancsarics Alajos, Gedeon Árpád, Nánási Tibor)

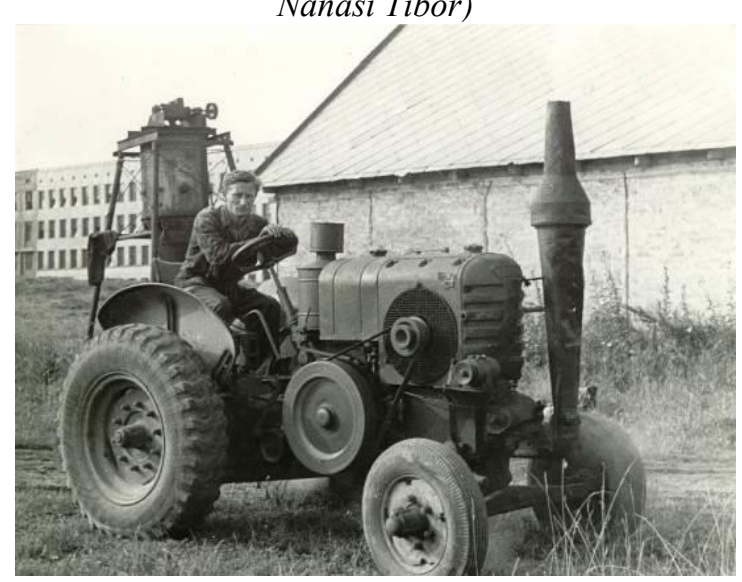

A tanszéki HSCS traktor

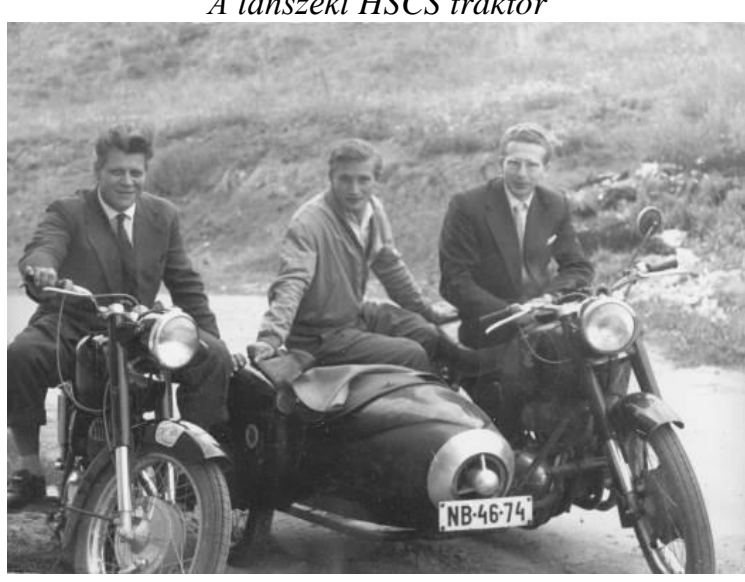

Tanszéki motorkerékpárok

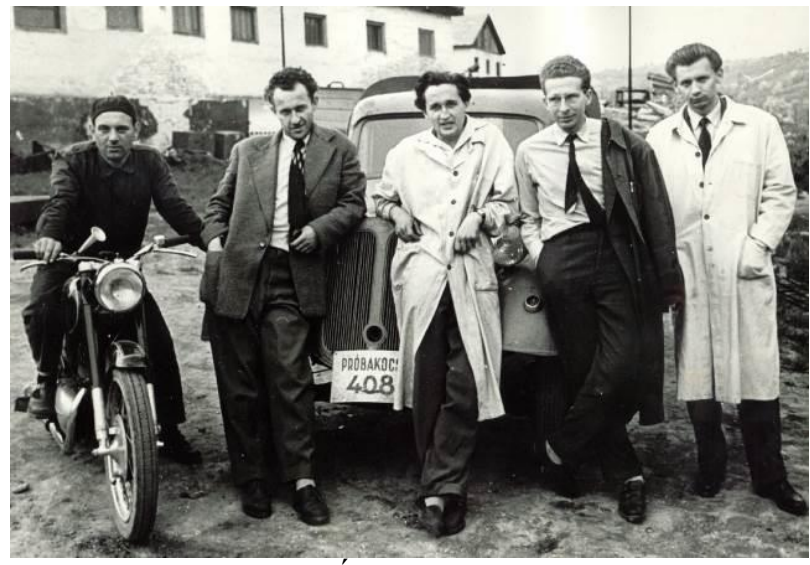

A „PRÓBAKOCSI 408”

(Babics László, Cserny József, Kassai Gyula, Hajós Mihály, Nánási Tibor)
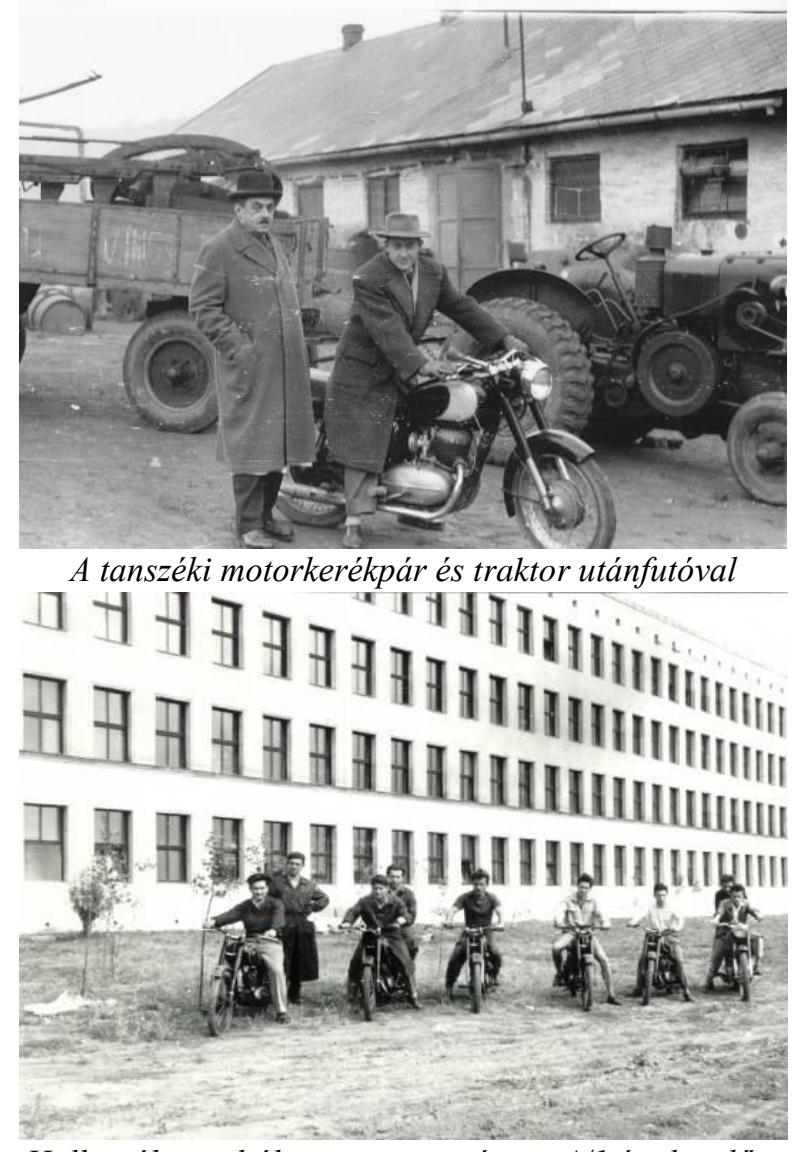

Hallgatók tanulják a motorvezetést az A/1 épület elött, távolabb a tanszéki tehergépkocsi

12. ábra. A Tanszék jármü eszközparkja az 1950-es években 
A laboratórium a 2007-es épületkorszerüsítést követően eszközparkjában is jelentősen fejlődött. Megépült a Lancsarics motorvizsgáló laboratórium (11. ábra jobb oldali képe), majd egy hütőbútorok tesztelésére szolgáló nagyméretü klímakamra. Az oktatási szemléltető eszközök terén jelentős javulást jelentettek a G.U.N.T cégtől beszerzett eszközök (13. ábra). A kutatási infrastruktúra is jelentős korszerüsödésen esett át. Modern, új mérőeszközök (LDA, CTA, PIV, termovízió) jelentik a kutatási infrastruktúra új irányvonalát. Az alapkutatási vizsgálatokhoz két újabb, kisebb méretủ légcsatorna épült (14. ábra).

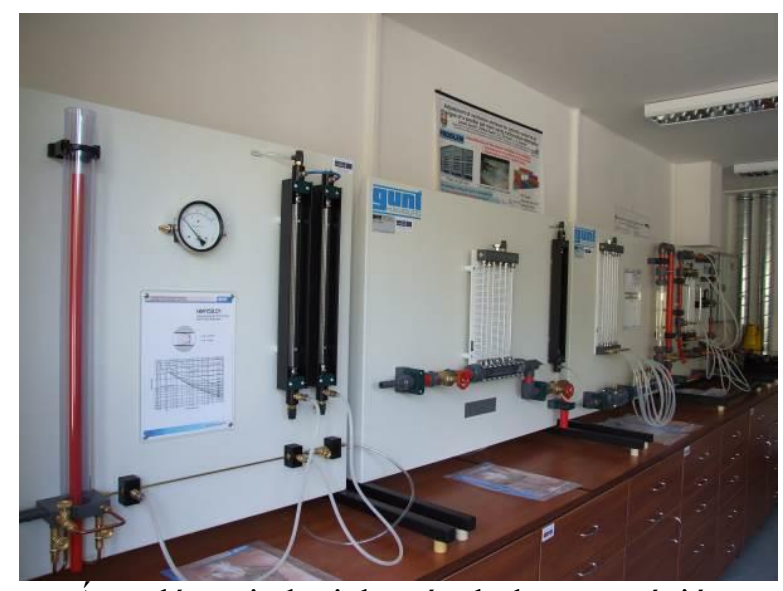

Áramlástani alapjelenségek demonstrációs eszközei

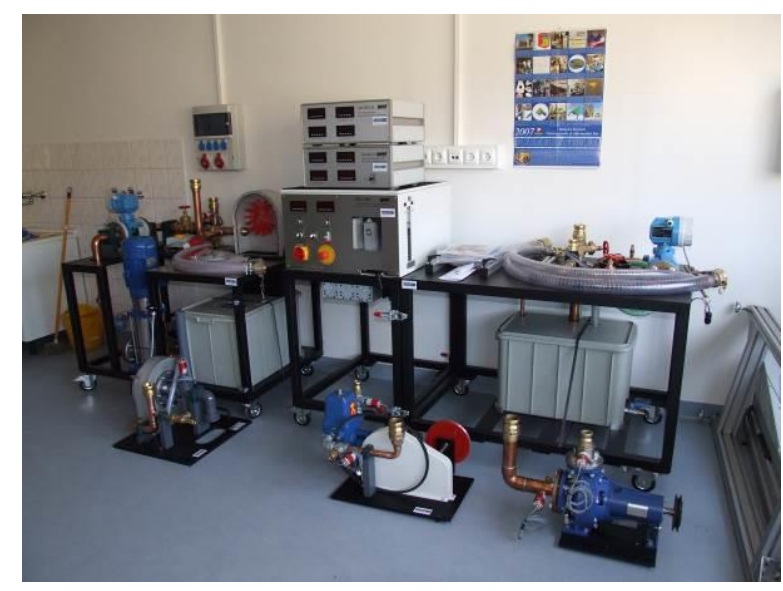

Szivattyúk, vízturbinák mérőberendezése

13. ábra. G.U.N.T. oktatási demonstrációs berendezések a vizgépészeti laboratóriumban

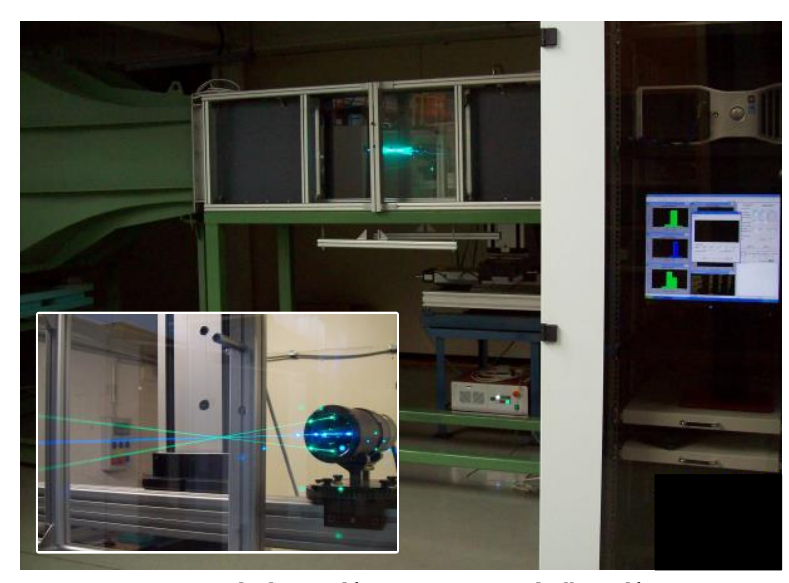

LDV mérés szélcsatorna mérőterében

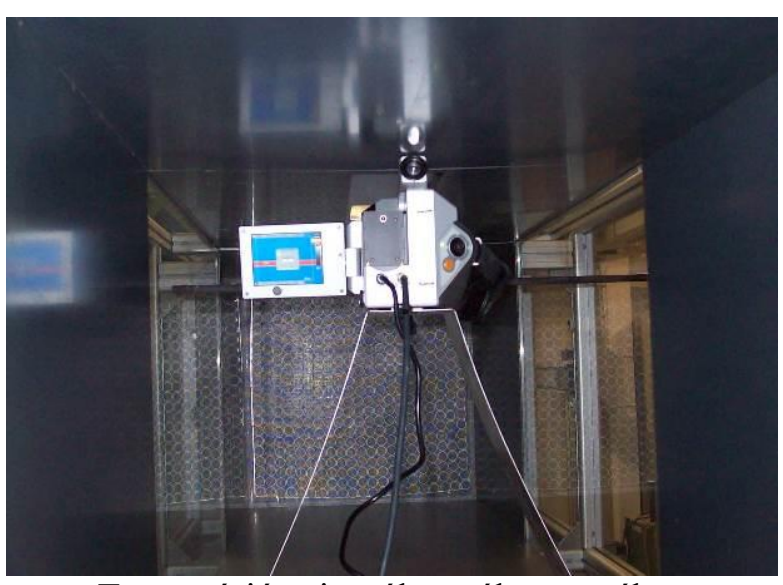

Termovíziós vizsgálat szélcsatornában

14. ábra. Áramlás-és hötechnikai mérések az egyik új szélcsatornában

\section{Oktatási tevékenység}

A Tanszék alapításakor az Egyetemen még csak a három müszaki karon folyt az oktatás. A Tanszék oktatási munkája mindhárom karra kiterjedt és kezdetben a géprajz oktatása mellett hőerőgépek és 
bányaszivattyúk tartoztak hozzánk (2. táblázat) A következő években a géprajz oktatását más tanszékek vették át és fő profilként az áramlás- és hőtechnika szakterületre eső alap- és szaktárgyak honosodtak meg. A közben megindult esti, majd levelező oktatás tovább növelte a feladatokat. A változást jelezte a Tanszék nevének Gépüzemtan Tanszékröl Áramlás- és Hőtechnikai Gépek Tanszékére való változtatása.

2. táblázat. A Tanszék első évében (1952-53-as tanév) oktatott tárgyai

\begin{tabular}{|c|c|c|c|c|c|}
\hline \multirow{2}{*}{ félév } & \multirow{2}{*}{ tárgy címe } & \multicolumn{2}{|c|}{ heti óraszám } & \multirow{2}{*}{ évfolyam } & \multirow{2}{*}{ szak } \\
\cline { 3 - 5 } & & elöadás & gyakorlat & & \\
\hline I. & Hőerőgépek üzemtana & 4 & 1 & III. & gépészmérnök+bányamérnök \\
\hline I. & Géprajz & 0 & 2 & II. & bányaművelő \\
\hline I. & Géprajz & 2 & 2 & II. & olajbányász \\
\hline I. & Géprajz & 0 & 3 & II. & vas- és fémkohász \\
\hline I. & Géprajz & 0 & 2 & II. & kohász technológus \\
\hline II. & Bányaszivattyúk & 2 & 2 & IV. & bányagépész \\
\hline II. & Gépelemek & 4 & 4 & II. & bányaművelő \\
\hline II. & Géprajz & 1 & 2 & II. & bányász geológus \\
\hline
\end{tabular}

Czibere Tibor tanszékvezetői tevékenységének megindultával az alaptárgyak színvonalának jelentős növekedése kezdődött. Az újonnan létrehozott Alkalmazott Mechanikai Ágazat keretein belül a Tanszék szakmai tudására alapozva megvalósult a Folyékony Kontinuumok Mechanikája speciális irány. Az ezen oktatási formában tanuló hallgatók magas színvonalú elméleti képzést kaptak. Nem véletlen, hogy mint már említettük, a Tanszék oktató gárdájának jelentős fejlesztése az 1970-es években ezen ágazaton végzett hallgatókra épült.

A nyolcvanas évek második felétől az országban bekövetkezett változások a Tanszék oktató munkájában is éreztették hatásukat. A TEMPUS programok keretében kitárult a világ az oktatók elött és számos külföldi egyetemen nyílt lehetőség tanulmányozni, és aztán a hazai viszonyok között alkalmazni a nyugat-európai tapasztalatokat. Ezzel párhuzamosan jelentős változások következtek be az oktatás területén. Bevezetésre került a moduláris oktatási rendszer. Ezt a változást Dr. Czibere Tibor kezdeményezte főleg a német és amerikai egyetemi módszerek tanulmányozása alapján. A megvalósítást Dr. Páczelt István dékán nagyrészt tanszékünkre bízta, ez a szervezést, egyeztetést és a szemléltető anyag elkészítését is jelentette. A rendszer ma is müködik. Megindult az önköltséges angol nyelvü oktatás, majd a föiskolai szintü képzés is helyet kapott az egyetem falai között. 1988-tól a kialakított magas elméleti színvonalú oktatás állandó továbbfejlesztése folyik. A tanszék tevékenységét befolyásoló fố tényezök:

- A számítástechnika robbanásszerü fejlődésével teljesen új területek (numerikus termo- és hidrodinamika) épültek be az oktatásba.

- Áttérés a moduláris jellegü oktatásra.

- Új szakok megjelenése (pl. informatikai, müszaki menedzser, mechatronikai mérnöki, energetikai mérnök)

- Átalakult a hagyományos mérnökképzés a kétlépcsős, BSc. -MSc. képzésre.

- Gazdái lettünk az új Energetikai Mérnök Alap- és Mesterszaknak.

- PhD képzésbe való bekapcsolódás.

- Idegen nyelvü képzések megjelenése stb. 
A fenti felsorolásból kiemelendő az Energetikai Mérnök képzés, amely 2005-től BSc., majd 2009től MSc. szinten a Tanszék kidolgozásában valósult meg, ellátjuk a szakvezető tanszéki teendőket is. Az Egyetem történetében mérföldkőnek tekinthető, hogy a szak szervezésben mindhárom müszaki kar együttmüködött, így kitünő oktatógárda készült fel a feladatra, élén négy akadémikussal. E szak napjainkig jelentős erőfeszítéseket igényel a Tanszék részéről, de számos új lehetőség forrásai is volt. A 15. ábra szélső képei a 2015.01.20-i államvizsga eredményhirdetését mutatják, a középső kép pedig az államvizsga résztvevőinek csoportképe az államvizsga után a Tiszavíz Kft.-től kapott vízturbina járókerék előtt. Ez a 4,8 m átmérőjű Kaplan-turbina járókerék sok-sok évi üzemelés után a felújítás során vált szabaddá a Tiszalöki Vízerőmüben. Az, hogy az egyetemi park különleges „mütárgya” lett, elsősorban a 2012-ben tragikus balesetben elhunyt Dr. Lakatos Károly kollégánknak, a vízenergiahasznosítás kiváló szakértőjének köszönhető. Egy-egy ilyen csoportkép tisztelgés az Ő emléke előtt is.

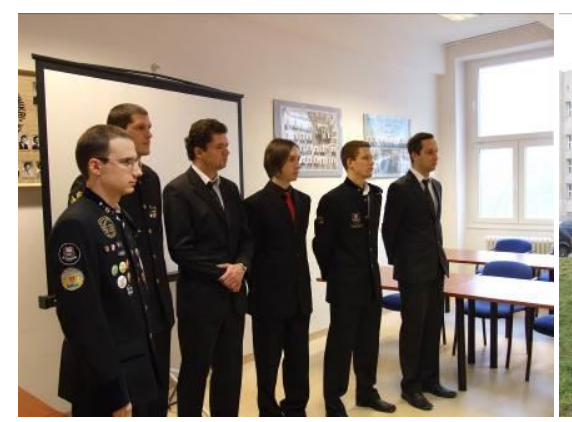

Az államvizsgázó hallgatók az eredményhirdetést hallgatják

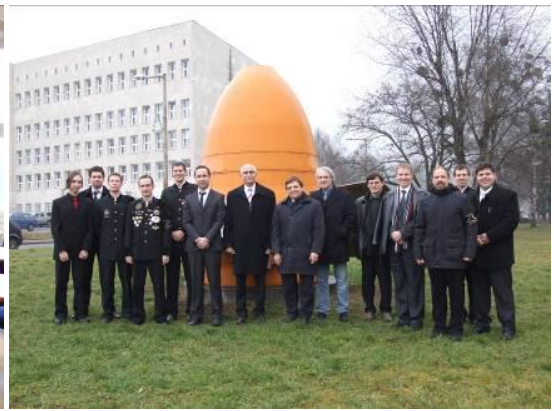

A résztvevők csoportképe

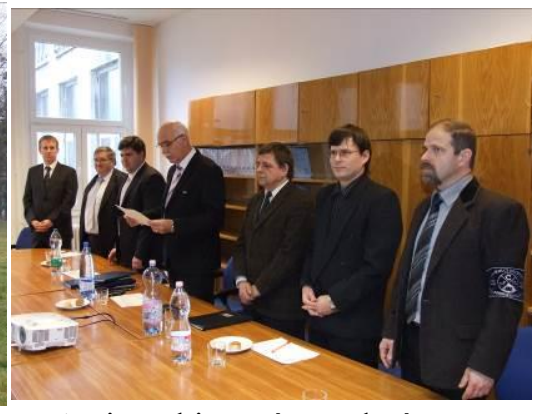

A vizsgabizottság eredményt hirdet

15. ábra. Az energetikus hallgatók államvizsgája 2015. január 20-án

\section{Kutatási tevékenység}

A Tanszék 1951-ben történt alapításától kezdve fontos feladatnak tekintette a kutatási tevékenységet. Az oktatás és kutatás összekapcsolásának igénye kezdettől fogva jellemezték a Tanszék tevékenységét. Így az alapítás nehézségein túljutva a tanszéki kutatómunka Lancsarics Alajos professzor vezetésével már az ötvenes években megindult. Kezdetben a kutatók az akkori oktatási profiloknak megfelelően elsősorban dugattyús gépekkel foglalkoztak. Az első jelentős, országos érdeklődésre számot tartó eredmény a dugattyúk hőmérsékletének mérésére alkalmas olvadószegecses eljárás kidolgozása [5] volt. Ez a méréssorozat úgy tekinthető, mint a tanszéki kutatási tevékenység erős indítása. A munka a Tanszék és a Jármüfejlesztési Intézet (JÁFI) együttmüködésének egyik eleme volt. Ez az együttmüködés tette lehetővé azt, hogy ha valaki a hatvanas évek elején belépett a 12. ábrán látható szegényes külsejü épületekbe, akkor ott egészen korszerü, nagyértékü motordiagnosztikai rendszereket talált. Maga az olvadószegecses mérés a hőtani ismeretek mellett logisztikai és munkaszervezési készséget is igényelt, hiszen egy-egy üzemállapot teljes körü vizsgálatához a motort (például egy hathengeres autóbuszmotort) sok-sok alkalommal szét kellett szedni, majd az új szegecskészlet rögzítése után indításra kész állapotba kellett hozni a fékpadon.

A jármümotorokkal kapcsolatos kutatómunka első hulláma a hatvanas évek végén zárult a ma már legendás Pannonia T5 és P20 motorkerékpár-típusok föszereplésével. Az általános üzemi jellemzők mellett a különleges cél a motor hütőbordáinak optimálása volt a méretek és az állásszög tekintetében.

Ehhez a tanszék szakemberei egy nyitott rendszerü, ipari méretű szélcsatornát terveztek két szabályozható fordulatszámú ventilátorral. A szerelvényeket miskolci üzemek (pl. Cementipari Gépjavító 
Vállalat, Lyukói Bányaüzem) készítették elő. A helyszíni szerelés, műszerezés és üzembe helyezés a tanszéki mühely feladata volt. A szélcsatorna $1,5 \times 1,5 \mathrm{~m}$ keresztmetszetü mérőszakaszán mintegy $80 \mathrm{~km} / \mathrm{h}$ szélsebesség volt elérhető. Az üzemelő motoron a szokásos diagnosztika mellett számos ponton mértünk hőmérsékletet. Speciális mechanizmusokat alakítottunk ki a motor (föleg a bordák) körüli áramlás vizsgálatára alkalmas gömbszondák mozgatásához. Természetesen a motoros személye sem hiányzott, a mühely dolgozói kedvelték ezeket az érdekes feladatokat. Ez volt az első szélcsatorna a Tanszéken (nagyon valószínü, hogy Miskolcon is).

A Tanszék egész tevékenységében és így természetesen a kutatómunkában is minőségi változás történt 1963-ban. Dr. Czibere Tibor került a Tanszék élére, akinek irányításával szervezett keretek közé került a kutatás, kialakultak a fö tanszéki kutatási irányok, amelyek még napjainkban sem veszítették el jelentőségüket. Jelentősen bővültek a nemzetközi és ipari kapcsolatok, amelyek fontos húzóerőt jelentettek. Az ezekben az években indult kutatások egyike, amely az áramlástechnikai gépekben lezajló áramlási viszonyok vizsgálatával foglalkozott, nemcsak hazai, hanem jelentős nemzetközi elismerést is hozott a Tanszéknek. A gépek lapátozásának a hidrodinamikai szingularitások módszerén alapuló számítási eljárása jelentősen hozzájárult ahhoz, hogy a tudományos világ magyar iskola elnevezéssel fejezze ki elismerését az áramlástechnikai gépek területén elért eredményekért $[6,7,8]$.

A hetvenes évektől a laboratóriumi lehetőségek bővülése és a sokoldalú tanszéki mühely lehetővé tették olyan áramlástechnikai kutatási módszerek alkalmazását, amelyek nyugaton már évtizedek óta meghonosodtak. Elsősorban a modellméréseket emeljük ki, ahol a tanszéki közösség tervei alapján a tanszéki mühely dolgozói készítették el a modelleket a társtanszékek segítségével. Az első lépés a Szabolcs-Szatmár Megyei Gabonaforgalmi és Malomipari Vállalattal együttmüködve a fémsilók szellőzési rendszerének fejlesztése volt. Az elméleti kutatások (áramlás szemcsés, ill. porózus közegben) eredményeit egyrészt egy siló 1:5 arányú modelljén, másrészt egy Baktalórántházán mérésre előkészített üzemi fémsilón ellenőriztük a megfelelő modelltörvények alkalmazásával.

A következő modellezés tárgya a Kabai Cukorgyár gyártási folyamatának meghatározó eleme, a Brieghel-Müller típusú előderítő volt. A Dr. Czibere Tibor által irányított elméleti áramlástani vizsgálatok után következtek a mérések, előbb a laboratóriumban egy bonyolult modell fékpadi méréseivel, majd az elöderítőn a gyárban.

A modellezés ezután már folyamatossá vált a laboratóriumban. Különösen jelentősek a Mátrai Erőmü, illetve az Inotai Alumíniumkohó füstgázrendszerének modellezései és a felújított szélcsatornában vizsgált épület- illetve üzemcsarnok modellek.

Természetesen más irányú kutatások is folytak a Tanszéken. Ezek közül még a hőtechnikai gépekben és berendezésekben kialakuló hőcsere-folyamatokkal foglalkozó tevékenység emelhető ki. A következőkben bemutatjuk az elmúlt évtizedek főbb kutatási területeit. Elsőként az alapkutatás jellegúeket, majd az alkalmazott kutatás témakörébe esőket vesszük sorra.

\section{ALAPKUTATÁSOK}

- A hidrodinamikai szárnyrácselmélet kiterjesztése áramlástechnika gépek lapátozott tereiben kialakuló áramlásokra.

- Háromdimenziós modell folyékony kontinuumok turbulens mozgásának elméleti vizsgálatára és numerikus meghatározására.

- Összenyomhatatlan súrlódásos folyadékáramlásba helyezett álló, oszcilláló vagy forgó körhenger körüli instacionárius áramlás direkt numerikus szimulációja.

- Fázisváltozással kísért hővezetési folyamatok vizsgálata.

- Kavitációs áramlások számítása. 


\section{ALKALMAZOZOTT KUTATÁSOK}

A Tanszék tématerületéhez tartozó alkalmazott kutatások döntő részében együtt jelentkeznek az áramlástani és a hőtani kérdések. Mégis lehetséges egy olyanfajta csoportosítás, amikor kiemeljük a folyamatok szempontjából meghatározó tényezőket.

\section{Áramlástechnikai gépekkel és berendezésekkel kapcsolatos vizsgálatok:}

- Numerikus módszerek kifejlesztése áramlástechnikai gépekben kialakuló áramlások számítására, valamint a járó- és vezetőkerekek hidraulikai tervezésére

- Szuperszonikus gázinjektorok kísérleti és elméleti vizsgálata.

- Erőmüvi füstgázrendszer áramlás- és hőtechnikai vizsgálata.

- Légtechnikai rendszerek számítása.

- Hidraulikus rendszerekben kialakuló tranziens és állandósult állapotú folyadékáramlások vizsgálata, lengésvédelmi berendezések müködésének ellenőrzése.

Hötechnikai gépekkel és berendezésekkel kapcsolatos vizsgálatok:

- Léghütők és légkondenzátorok laboratóriumi vizsgálata.

- Ürtechnológiai eszközök kifejlesztésére irányuló kutatások.

- Dobszárítók hőtechnikai modellje és üzemük optimálása.

- Erőművi és technológiai hütési folyamatok vizsgálata.

- Környezetvédelem, gépdiagnosztika.

\section{KUTATÁSI PÁLYÁZATOK}

A tudományos tevékenységet kutatási pályázatok is segítették, ezek közül sorolunk fel néhányat.

- Folyékony és szilárd rugalmas kontinuumok dinamikai kölcsönhatása (Országos Tudományos Kutatási Alap, az ismert rövidítés szerint OTKA),

- Görbült felületek közötti áramlás PIVD kísérletekkel összehangolt numerikus vizsgálata új turbulenciamodell alapján (Művelődési és Közoktatási Minisztérium, MKM),

- Háromdimenziós turbulenciamodell a Kármán-féle hasonlósági hipotézis általánosításával (Akadémiai Kutatási Pályázat, AKP),

- Turbulens áramlás félaxiális átömlésü áramlástechnikai gép lapátozott terében (OTKA),

- Sokfokozatú turbógépek szerkezeti réseiben kialakuló háromdimenziós határréteg-áramlás (OTKA),

- Vezetéses hőközlés többkomponensű rendszerekben fázisátalakulása (FKFP).

- Áramlástechnikai gépek dinamikai vizsgálata (OTKA müszerpályázat),

- Közegárammérő eszközök hitelesítésére alkalmas munkahely kialakítása (OTKA müszerpályázat),

- Új háromdimenziós turbulenciamodell kifejlesztése és alkalmazása (FKFP),

- Vegyipari és energetikai rendszerekben keletkező szennyező anyagok környezeti hatásainak vizsgálata klimatizált szélcsatornában (OTKA),

- Rúd- és kötélszerkezetek körüli periodikus áramlási jelenségek számítása (Súrlódásos áramlásba helyezett prizmatikus testről leváló örvények direkt numerikus szimulációja) (OTKA).

- Konvektív hö- és anyagtranszport (FKFP)

A kutatási tevékenység eredményeképpen a PhD fokozat bevezetése óta a Tanszék szakmai vezetésével kilencen szereztek doktori fokozatot és ketten habilitáltak.

Az elmúlt időszakban a hétköznapi politikai érdeklődés középpontjába került a klímavédelem (klímakatasztrófa!), globális felmelegedés, széndioxid kibocsátás stb. kérdése. Megállapítható, hogy ezek a témák már a nyolcvanas évektől a tanszéki oktatás és kutatás súlypontjában voltak. Az Energetikai 
Mérnök Alap-és Mesterszak másról sem szól, mint arról, hogy hogyan lehetne a környezetszennyezést csökkenteni, miközben a hazai villamos energiafogyasztás csúcsteljesítménye hétezer megawatt fölé nőtt. A Tanszék vállalta a profiljától kissé távol álló Szennyvízkezelés és Hulladékfeldolgozás oktatását, megszerveztük az épületenergetikai auditorok képzését. Kutatási témáink szinte mindegyike tartalmaz környezetvédelmi elemeket (füstgáztisztítás, pontosabb motordiagnosztika, LEGYENER, Schumacher-gyertyák, energiatakarékos háztartási gépek fejlesztése, zajcsökkentés, abszorpciós höszivattyúk energetikája, stb.).

\section{Ipari kapesolatok}

A Tanszék - alapításától fogva - élénk ipari kapcsolatokkal rendelkezett. Az első 4 évtizedben főleg a hazai ipari nagyvállalatok számára végezett a Tanszék tervezési, kutatási, fejlesztési tevékenységeket. E munkák során nagy szerep jutott a tanszéki laboratóriumnak, de számos esetben helyszíni mérések is a feladatok közé tartoztak. Ilyen vállalatok voltak például a Ganz-Mávag, a Diósgyőri Gépgyár, a MOL, a Vegyépszer.

A rendszerváltozás az ipari kapcsolatokban is változást hozott. Megjelentek a kis- és közepes vállalatok, amelyek nem tudtak fenntartani saját fejlesztő részleget. E cégektől a Tanszék sok kisebbnagyobb tervezési, fejlesztési munkát kapott. A változás másik jellemzője az volt, hogy a nemzetközi nagy cégek birtokába került nagyvállalatok sokszor készen kapták a külföldi fejlesztési eredményeket, illetve az új feladatokat szívesebben végeztették el az anyacég fejlesztő központjaiban. A harmadik változás viszont pozitív. Kormányzati segítséggel olyan néhány éves projekteket támogattak, amelyek az ipar és a felsőoktatás kutatás-fejlesztési tevékenységét segítették, rendszeressé, szervezetté tették. Ilyenek voltak például a 2001-ben alakult Mechatronikai és Anyagtudományi Kooperációs Kutatási Központ, vagy a 2005-ben létrejött Mechatronikai és Logisztikai Regionális Egyetemi Tudásközpont. E szervezetek keretei között a Tanszék szoros kutatás-fejlesztési kapcsolatban állt az alábbi cégekkel: MAL Magyar Alumínium Termelő és Kereskedelmi Rt., Electrolux Lehel Kft. Porszívógyára és Hütőgépgyára, Tiszai Vegyi Kombinát, Zollner Elektronik Kft., Dometic Zrt., Robert Bosch Power Tool Kft. A 2008-tól az Új Széchenyi terv támogatásával GINOP pályázat keretében müködtetett UNIFLEXYS Egyetemi Innovációs Kutató és Fejlesztő Közhasznú Nonprofit Kft. segítette az ipari szereplökkel a kapcsolattartást, például a következőkkel: Tiszavíz Vízerőmü Kft., SZATEV Zrt,. Beregvíz Kft., Audi Hungária Kft., Electrolux Lehel Kft.

A jubileumi évben a Tanszék nemzeti GINOP pályázatok keretében végzett kutatómunkát az alábbi cégek számára: Robert Bosch Energy and Body Systems Gépjármű elektromossági Alkatrész Gyártó és Forgalmazó Kft., Starters E-Components Generators Automotive Hungary Kft.

Természetesen e szervezett kereteken kívül is eseti megkeresésre számos szakmai feladat megoldásában segítette a Tanszék az ipari szereplőket. A sokrétü tevékenysége jellemzésére legyenek példaként felsorolva a legkülönfélébb vállalatok, akiket az köt össze, hogy áramlástani, hőtani és energetikai problémákkal keresték meg a Tanszéket: Nitrogénmüvek Zrt., Mátrai Erőmü Rt., MOL Magyar Olaj- és Gázipari Rt., RAABVILL Kft., Ventifilt Légtechnikai Rt., Miskolci Sütőipari Kft., Dispomedicor Zrt., Dunaferr Dunai Vasmü Rt., Columbian Tiszai Koromgyártó Kft., Paksi Atomerömü Zrt. A felsorolásban esetleg több olyan intézet és cég is található, amely időközben profilt váltott, vagy a való világból a gazdaságtörténet lapjaira költözött. Az ezekhez kapcsolódó kutatási eredmények természetesen nem vesztek kárba, hiszen a módszerek és eszközök tovább hasznosíthatók, az eredmények pedig a tananyagba beépítve (erre mindig törekedtünk) az újabb nemzedéket segítik a továbblépésben. 


\section{Nemzetközi kapcsolatok}

A Tanszék fennállásától kezdve igyekezett a kor lehetőségeinek keretén belül kiépíteni és fenntartani nemzetközi kapcsolatait. Az első évtizedekben a volt szocialista országok társegyetemeivel alakultak ki hasznos kapcsolatok. A magdeburgi Otto von Guericke Egyetem, a Kassai Egyetem, A Zsdánovi Egyetem, a Freibergi Egyetem stb. jelentették a kapcsolatok bázisát. A rendszerváltás után kinyíltak a kapuk, a tanszék munkatársai látogatták a világ különböző részein rendezett konferenciákat és szereztek személyes kapcsolatokat, amelyek közül néhány később intézményi kapcsolattá is vált. Ezek közül néhány fontosabb: Universität Magdeburg (Németország), Dalian University of Technology (Kína), Cranfield University (U.K.), University of Western Macedonia, Kozani (Görögország), Nagaoka University of Technology (Japán), Indian Institute of Technology, Roorkee (India), Ecole Politechnique Montréal, QC, (Kanada), Harbin Institute of Technology, Shenzhen (Kina), Universität Siegen (Németország), Technická Univerzita v Kosiciah (Szlovákia), University College London (U.K), Universität Karlsruhe (Németország), Universität Aschaffenburg (Németország), University of West Bohemia (Csehország), KTH Royal Institute of Technology (Svédország), Karlsruher Institut für Technologie (Németország), University of Pretoria (Dél-afrikai Köztársaság), Turboinštitut Ljubljana (Szlovénia), Ben Gurion University (Izrael), TU Claustahl (Németország).

A kétezres évek elején több tanszéki doktoranduszunk használta ki azt, hogy tanulmányai során kapcsolatokat építhetett ki tekintélyes európai egyetemeken. Ma már megbecsült oktatói-kutatói az adott intézménynek. Tanszékünk ezt oktatási rendszerünk elismerésének tekinti, de itthon hiányoznak.

\section{7. Összefoglalás}

A Miskolci Egyetem Áramlás- és Hőtechnikai Gépek Intézeti Tanszék az 1952-ben alapított Gépészmérnöki Kar 70 éves fennállásából 67 éve egyik meghatározó tanszéke a Karnak. Olyan szakterületeket müvel, amelyek a gépészeti tárgyú müszaki egyetemek mindegyikében müvelt diszciplínák. Az áramlás- és hőtechnika, valamint az energetika ugyanis a cégek, intézmények profiljától függetlenül mindenhol jelen van, ezért a felsőoktatás szintjén müvelésük mindenképpen indokolt. A közel hét évtizedet áttekintve bemutattuk a tanszék történetét, oktatási-kutatási tevékenységét és ipari, valamint nemzetközi kapcsolatait.

\section{Köszönetnyilvánítás}

A cikkben ismertetett kutató munka az EFOP-3.6.1-16-2016-00011 jelü „Fiatalodó és Megújuló Egyetem - Innovatív Tudásváros - a Miskolci Egyetem intelligens szakosodást szolgáló intézményi fejlesztése" projekt részeként - a Széchenyi 2020 keretében - az Európai Unió támogatásával, az Európai Szociális Alap társfinanszírozásával valósul meg.

\section{Irodalom}

[1] A Tanszék története, GÉP, 2012/9, pp. 3-4. ISSN 0016-8572

[2] Czibere, T., Vida, Gy., Karaffa, F.:25 éves az NME Áramlás-és Hötechnikai Gépek Tanszéke A Nehézipari Müszaki egyetem Közleményei, III. sorozat, Gépészet, 23. kötet-4. füzet, Miskolc, 1977

[3] Áramlás- és Hôtechnikai Gépek Tanszéke, Jubileumi Évkönyv, 1949-2009, Miskolc, 2009, pp.42-45. 
[4] Karaffa, F. Schifter, F.: Bemutatkozik az Áramlás- és hötechnikai Gépek Tanszéke, GÉP, 2003/1, pp. 5-13, ISSN 0016-8572

[5] Lancsarics, A.: Jármü dieselmotorok dugattyúfelületein fellépö hömérséklet mérése, A Nehézipari Müszaki egyetem Közleményei, I. kötet Miskolc, 1957 pp. 259-269.

[6] Czibere, T.: Berechnungsverfahren zum Entwurfe gerader Flügelgitter mit stark gewölblen Profilschaufeln, Acta Technica XXVIII, Budapest 1960, pp. 43-71, 241-280.

[7] Czibere, T.: Méretezési eljárás erösen ivelt profilos lapátokból álló egyenes szárnyrács tervezéséhez, Kandidátusi értekezés, 1963

[8] Czibere, T.: A hidrodinamikai rácselmélet két föfeladatának potenciálelméleti megoldása, Akadémiai doktori értekezés, 1967 